\title{
Investigation of Amino and Fatty Acid Characterisation of Thevetia peruviana (Milk Bush) Seed
}

\author{
Akintelu M. T. ${ }^{* 1}$, Amoo I. A. ${ }^{2}$, Kade I. $\mathrm{J}^{3}$, Omoba O. $\mathrm{S}^{4}$ \\ ${ }^{1}$ Department of Chemical Sciences, \\ Samuel Adegboyega University, \\ Ogwa, Edo State. \\ ${ }^{2}$ Department of Chemistry, \\ Federal University of Technology, \\ Akure, Ondo State, Nigeria. \\ ${ }^{3}$ Department of Biochemistry, \\ Federal University of Technology, \\ Akure, Ondo State, Nigeria. \\ ${ }^{4}$ Department of Food Science, \\ Federal University of Technology, \\ Akure, Ondo State, Nigeria.
}

Email: marytoyetunji@gmail.com

\begin{abstract}
This study examined the amino acid profile and fatty acid analysis of Milk bush (thevetia peruviana) seed. The seeds were ground into very fine powder using three processing techniques. The parameters of interest were carried out using standard methods. The results of both essential and non-essential amino acids showed that the total essential amino acid content in oven-dried seed sample (OD.S), airdried seed sample (AD.S) and sun-dried seed sample (SD.S) were within the WHO Standard. It was observed that eighteen out of the twenty amino acids content of food were present in the seed with glutamic acid having the highest value, followed by aspartate and arginine. Also the eight essential amino acid needed in the daily diet were all present in the sample (arginine, valine, histidine, isoleucine, lysine, methionine, phenylanine, threonine, tryptophan and leucine). There were reductions in the level of some amino acids as a result of the processing treatments. The fatty acid analysis also revealed that the sample contained both saturated and unsaturated fatty acids. The unsaturated fatty acids for oven-dried, sun-dried and air-dried are 60.89, 2.21 and 20.47 respectively while the saturated fatty acids for oven-dried, sun-dried and air dried 26.15, 3.29 and 35.61 respectively. The result suggested that thevetia peruviana contains high quality protein and the oil is a good source of unsaturation which increases the shelf life and edibility of the oil.
\end{abstract}

Keywords: Amino acid; Fatty acid; Characterization; Processing techniques; Milk-bush seed

\section{INTRODUCTION}

Thevetia peruviana belongs to Apocynaccae family and it is commonly called yellow oleander. Its seed comprises a milky sap with a compound known as thevetin which can be 
applied as heart stimulant and is naturally poisonous including the entire parts of the plant especially the seed (Iorliam and Yarkwan, 2013; Akintelu and Amoo, 2017). It leaves are long lance shaped and green in colour. It possesses a waxy coated leaves that prevent water loss. The flowers are funnel-like with petals that are spirally twisted. The fruits are somewhat globular, with fleshy mesocarp and have a diameter of $4-5 \mathrm{~cm}$. Each fruit contains a nut which is longitudinally and transversely divided and has one to four seeds in its kernel. Amino acids are the building blocks of protein which play a key role in cellular processes, such as nitrogen metabolism, energy generation, intracellular communication and cell wall synthesis (Stryer, Berg and Tymoczko, 2002). It is an organic molecule which is made up of basic amino group $\left(-\mathrm{NH}_{2}\right)$, an acidic carboxyl group $(-\mathrm{COOH})$ and a unique organic $\mathrm{R}$ group or side chain. They are said to be the building blocks of protein joined together by peptide bond through the condensed polymerisation with elimination of water molecules between $\mathrm{NH}_{2}$ and $\mathrm{COOH}$ group (Clark and Creswell, 2007). The last of the 20 common amino acids to be discovered was threonine in 1935 by William Cumming Rose, who also determined the essential amino acids and established the minimum daily requirements of all amino acids for optimal growth (Simoni, Hill and Vaughan, 2002).

Plants are significant ultimate source of nutrition for animal species because they have a special capacity of synthesizing proteins, carbohydrate, oils and absorbing minerals directly from the soil. The Kernels and defatted cakes of many unused oil seed are good sources of protein and glycerides (Ogara, 2013).

Most of the proteinous oilseeds on which work has been well documented namely cotton seed, cowpea, soybean, groundnut, and rapeseed are protein sources not just for animals but also for man. This has therefore, led to a competition between man and animal for food, which consequently resulted in the scarcity and a high price of these oilseeds. Hence, there is need to develop novel protein sources that will serve as food just for animal consumption, thereby eliminating the competition between man and animals. Nutritionists around the world are attempting to approach this problem by developing novel foods from non conventional protein sources such as algae protein, single cell protein and insect protein. Another approach to the problem is the detoxification of many abundant oilseeds indigenous to the tropics, which are not yet fully utilized because of toxins and antinutrients in them. One of such oil seeds is Thevetia peruviana (Oluwaniyi et al. 2011).

It can put up with most types of soil as long as they are well drained and are located in full sun in a protected area. It can grow in diverse places such as contaminated soil (Usman et al., 2009). It is used as a pest control and heart strengthening (Bandara et al., 2010; Singh et al., 2012; Koushik et al., 2016). This plant is used for biological pest control and the seeds oil can be used as an antifungal, anti-bacterial, anti-termite purposes (Roberts et al. 2006; Rajapaske, 2009; Koushik et al. 2016). Ayoade et al. (2017) have worked on amino acids profile of (Anarium schweinfurthii) seed pulp. Farid et al. (2018) also investigated amino acid analysis of four safflower (Carthamus tinctorius L) varieties grown in North-eastern Morocco. Their studies showed varying degree of amino acids content. Based on the various usefulness of the thevetia peruviana plant and the fact that there is paucity of information on the study of amino acid content of Thevetia peruviana the study tends to investigate the amino acid profile and fatty acid characterisation of Thevetia peruviana seed.

\section{MATERIALS AND METHOD}

\section{Area of study}


The aimed at investigating amino acid profile and fatty acid characterisation of Milk bush fruit. Specifically, the back, shell and seed of Thevetia peruviana fruit using three processing techniques.

\section{Collection of samples}

The Thevetia peruviana seed used in this study was obtained from Lafe area along Ondo road, Akure, Nigeria. The fruits were collected and sorted into its three layers which include the fruit back, shell and seed. These three layers were oven dried, air dried and sun dried. Prior to laboratory experiment, the samples was further ground to powder, packed in airtight sample plastics and preserved in refrigerator at $4^{\circ} \mathrm{C}$.

\section{Laboratory procedures}

\section{Amino acid profile}

Extraction and the instrumentation analysis were carried out by the following modified method (A.O.A.C, 2005; Danka, Dobrina and Kalin, 2012).

The dried and pulverized sample was made to be free of water by ensuring constant weight for a period of time in the laboratory. The sample of $0.5 \mathrm{~g}$ was weighed into $250 \mathrm{ml}$ conical flask capacity. The sample was defatted by extracting the fat content of the sample with $30 \mathrm{ml}$ of the petroleum spirit three times with soxhlet extractor that was equipped with thimble. The sample was hydrolyzed three times for complete hydrolysis to be achieved for the totality of amino acids recovery. The pulverized and defatted sample was soaked with $30 \mathrm{ml}$ of the $1 \mathrm{M}$ potassium hydroxide solution and was incubated for $48 \mathrm{hrs}$ at $110^{\circ} \mathrm{C}$ in hermetically closed borosilicate glass container. After the alkaline hydrolysis, the hydrolysate was neutralized to get $\mathrm{pH}$ in the range of $2.5-5.0$. The solution was purified by cation-exchange solid-phase extraction. The amino acids in purified solution were derivatised with ethylchloroformate by the established mechanism.

\section{Derivative mechanism}

The derivatization of the extracted amino acids for the volatility sake in the gas chromatography with ethyl chloroformate is as described with the reaction below:

The derivatising reagent removed by scavenged with nitrogen gas for proper mop up of the excess reagent. The derivatised amino acid that is free of deriavatising reagent was made up to $1 \mathrm{ml}$ in a vial for gas chromatography.

\section{The GC conditions used for Amino acids analysis are of standard specifications} includingHP 6890 Powered with HP Chemstation Rev. A09.01 [1206] Software, split injection temperature,20:1 split Ratio,Hydrogen carrier gas $1.0 \mathrm{ml} / \mathrm{min}$ flow rate, $250^{\circ} \mathrm{C}$ inlet temperature, EZ column type, $10 \mathrm{~m}$ X $0.2 \mathrm{~mm}$ X $0.2 \mu \mathrm{m}$ column dimension, Initial @ $110^{\circ} \mathrm{C}$ oven programme, PFPD/FID detector, $320^{\circ} \mathrm{C}$ detector temperture, 20psi hydrogen pressure and 35psi compressed air.

\section{Fatty acid analysis}

The fatty acid composition for air-dried, sun-dried and oven-dried sample of Thevetia peruviana was determined by Damila et al., (2017) method using their methyl ester which were separated by gas chromatography in a trace ultra 3300model (Thermo Scientific) equipped with a flame ionization detector (FID) and a cyanopropyl capillary column (100m x0.25 internal diameter, $0.25 \mu \mathrm{m}$ film thickness, CP 7420 Varian, EUA). The injector and detector temperatures were $240^{\circ} \mathrm{C}$. The gas flow rates used were $1.2 \mathrm{ml} \mathrm{min}^{-1}$ for carrier gas

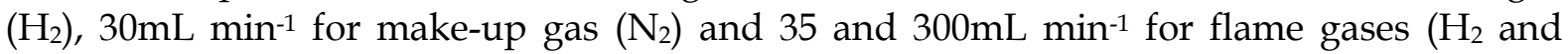
synthetic air, respectively). The operational parameters were as follows: the column temperature was held at $185{ }^{\circ} \mathrm{C}$ for $7.5 \mathrm{~min}$, programmed to increase at $4{ }^{\circ} \mathrm{C} \mathrm{min}^{-1}$ to $235{ }^{\circ} \mathrm{C}$, 
and maintained at this temperature for $1.5 \mathrm{~min}$; the total run time was $25 \mathrm{~min}$. The peak areas were determined by ChromQuest 5.0 software. For FA identication, retention times were compared with those of standard methyl esters. Quantification (in milligrams of FA per gram of TL) was performed against tricosanoic acid methyl ester as an internal standard (23:0). Theoretical FID correction factor values were used to obtain concentration values. FA content was calculated in milligrams per gram of TL by using the equation 1 :
$\mathrm{FA}\left(\mathrm{mg}^{-1}\right.$ of TL) $=\frac{\mathrm{Ax} \mathrm{W}_{\mathrm{IS}} \mathrm{CFx} \quad \mathrm{X} 100}{\mathrm{~A}_{\mathrm{IS}} \mathrm{Wx} \mathrm{CF}_{\mathrm{AE}}}$

Where FA is expressed in milligrams per gram of TL, Ax is the peak area (FA), $\mathrm{A}_{\mathrm{IS}}$ is the peak area of the internal standard (IS) methyl ester of tricosanoic acid (23:0), $\mathrm{W}_{\text {IS }}$ is the IS weight (mg) added to the sample (in $\mathrm{mg}$ ), Wx is the sample weight (in $\mathrm{mg}$ ), CFx is the theoretical correction factor and $\mathrm{CF}_{\mathrm{AE}}$ is the conversion factor necessary to express results as milligrams of FA rather than as methyl esters. The results were converted to milligrams of FA per $100 \mathrm{~g}$ of sample on a dried basis (mg per $100 \mathrm{~g} \mathrm{DB}$ ).

\section{RESULTS AND DISCUSSION}

Amino acid analysis of Thevetia peruviana seed

The essential and non-essential amino acids as well as the amino acid quantity $(\mathrm{g} / 100 \mathrm{~g})$ were analysed using oven-dried, air-dried and sun-dried techniques (Table 1). The result revealed that four (Threonine; 3.45, 3.44, 3.38; Lysine; 1.21, 4.11, 2.20; Phenylalanine; 3.56, 3.56, 3.50; Methionine; 6.57e-1, 1.09, 1.07) out of the nine essential amino acid parameters contained in the seed sample are within WHO standard (Table 1) for oven-dried, air-dried and sun-dried samples respectively. However, there is sufficient amount of valine essential amino acid content especially the oven-dried (2.70) and sun-dried (2.59) sample of Thevetia peruviana seed. However, for tryptophan and leucine, only one processing technique (airdried:1.15 and sun-dried: 6.62) shown to follow WHO standard. Table 1 also present the non-essential amino acid content of the seed sample of T. peruviana.

It shows that the respective amounts of amino acids $(\mathrm{g} / 100 \mathrm{~g})$ in oven dried seed sample (OD.S), air dried seed sample (AD.S), sun-dried seed sample (SD.S), sun-dried (flesh) Back (SD.B) and sun dried Inner sample (SD.I) are Glycine (2.98, 3.40, 3.11, 4.16 and 4.68); Alanine (4.64, 4.43, 4.76, 3.79 and 3.46); Serine (2.48, 2.74, 2.77, 4.60 and 5.33); Proline (3.14, 3.09, 3.81, 3.79 and 2.71); Aspartate (13.61, 13.48, 14.85, 11.59 and 13.14); Glutamate $(18.76,16.65,17.15$, 16.42 and 19.15) Arginine (9.54, 10.04, 13.08, 6.58 and 5.58); Tyrosine (2.37, 2.03, 2.53, 3.52 and 3.57) and Cystine $(1.51,1.85,1.79,1.29$ and 1.35).

The Total Amino Acids (TAA) Content of the OD.S, AD.S, SD.S, SD.B and SD.I were (86.05522, 89.16821, 90.78897, 90.72878 and 93.77140); Total Essential Amino Acids Content (27.012993, 31.46274, 27.89456, 34. 99766 and 34.79950); Total Non-Essential Amino Acids (59.04, 57.71, 62.89, 55.79 and 58.97) and Total Sulphur Amino Acids (2.17, 2.95, 2.87, 2.35 and 2.25$) \mathrm{g} / 100 \mathrm{~g}$ respectively. Figure 1-5 also shows the chromatogram output of the peak area of each amino acid profile for both essential and non-essential.

Table 1: Amino Acid Analysis of Thevetia peruviana seed (Amount g/100gProt.)

\begin{tabular}{|l|c|c|c|c|c|}
\hline \multicolumn{1}{|c|}{ Parameters } & OD.S & AD.S & SD.S & SD.B & SD.I \\
\hline Glycine & 2.98101 & 3.39747 & 3.11315 & 4.15813 & 4.68239 \\
\hline Alanine & 4.64324 & 4.43307 & 4.76172 & 3.78638 & 3.45696 \\
\hline Serine & 2.48013 & 2.73548 & 2.77310 & 4.60393 & 5.32994 \\
\hline Proline & 3.13797 & 3.08603 & 3.81932 & 3.78923 & 2.71241 \\
\hline
\end{tabular}




\begin{tabular}{|c|c|c|c|c|c|}
\hline Valine & 2.70395 & 4.65332 & 2.59809 & 5.28324 & 3.11040 \\
\hline Threonine & 3.45091 & 3.44314 & 3.38379 & 4.20768 & 4.38129 \\
\hline Isoleucine & 4.35529 & 4.30998 & 4.26463 & 3.94523 & 3.80203 \\
\hline Leucine & 6.97631 & 6.72565 & 6.62638 & 6.91056 & 8.81174 \\
\hline Aspartate & 13.61202 & 13.48214 & 14.87346 & 11.58878 & 13.14201 \\
\hline Lysine & 1.21984 & 4.11378 & 2.20719 & 5.18128 & 7.17860 \\
\hline Methionine & $6.57523 \mathrm{e}-1$ & 1.09555 & 1.07729 & 1.06573 & $9.05126 \mathrm{e}-1$ \\
\hline Glutamate & 18.75948 & 16.64869 & 17.14940 & 16.42064 & 19.15407 \\
\hline Phenylalanine & 3.56510 & 3.56218 & 3.50375 & 4.77190 & 4.06363 \\
\hline Histidine & 2.05957 & 2.39992 & 2.36997 & 2.54184 & 1.70727 \\
\hline Arginine & 9.54295 & 10.04062 & 13.08271 & 6.57786 & 5.57790 \\
\hline Tyrosine & 2.37463 & 2.02999 & 2.52827 & 3.51563 & 3.56760 \\
\hline Tryptophan & 2.02450 & 1.15922 & 1.86347 & 1.08720 & $8.39414 \mathrm{e}-1$ \\
\hline Cystine & 1.51082 & 1.85196 & 1.79328 & 1.29055 & 1.34864 \\
\hline TOTAL & 86.05522 & 89.16821 & 90.78897 & 90.72878 & 93.77140 \\
\hline
\end{tabular}

Key: OD.S = Oven dried sample, AD.S=Air dried sample, SD.S=Sun dried sample SD.I=Sun dried inner

In the essential amino acid profiles of OD.S, AD.S, SD.S, SD.B and SD.I in this present study, the mean values of most of the essential amino acids reported for samples on Table 1 , considerably disagrees with the values (Lysine: 0.63-0.84 and Methionine: 0.16-0.30) reported by Farid et al. (2018) but agrees with the values (Lysine $3.51 \pm 0.02$ and Methionine $1.63 \pm$ 0.01) reported by Ayoade et al. (2017). Glutamate acid is the main amino acid, its content varies between (16.42- 19.15) g/100gProt. Followed by Aspartate acid (11.58- 14.87) g/100gProt; Arginine acid (5.57- 13.08) g/100gProt; Leucine acid (6.62- 8.81) g/100gProt. The high levels of glutamate and aspartate acids could be due to the experimental conditions that could cause the transformation of glutamine and asparagine into glutamate and aspartate acids respectively. Glutamate in SD.I (sun dried Inner) is higher than what is obtained in (OD.S, SD.S, AD.S and SD.B) with values in $\mathrm{g} / 100 \mathrm{~g}$ at 19.15, 18.75, 17.14, 16.64 and 16.42 respectively with all values considerably higher than the (FAO/WHO, 1991). 
ript of window 38: Current Chromatogram(s)

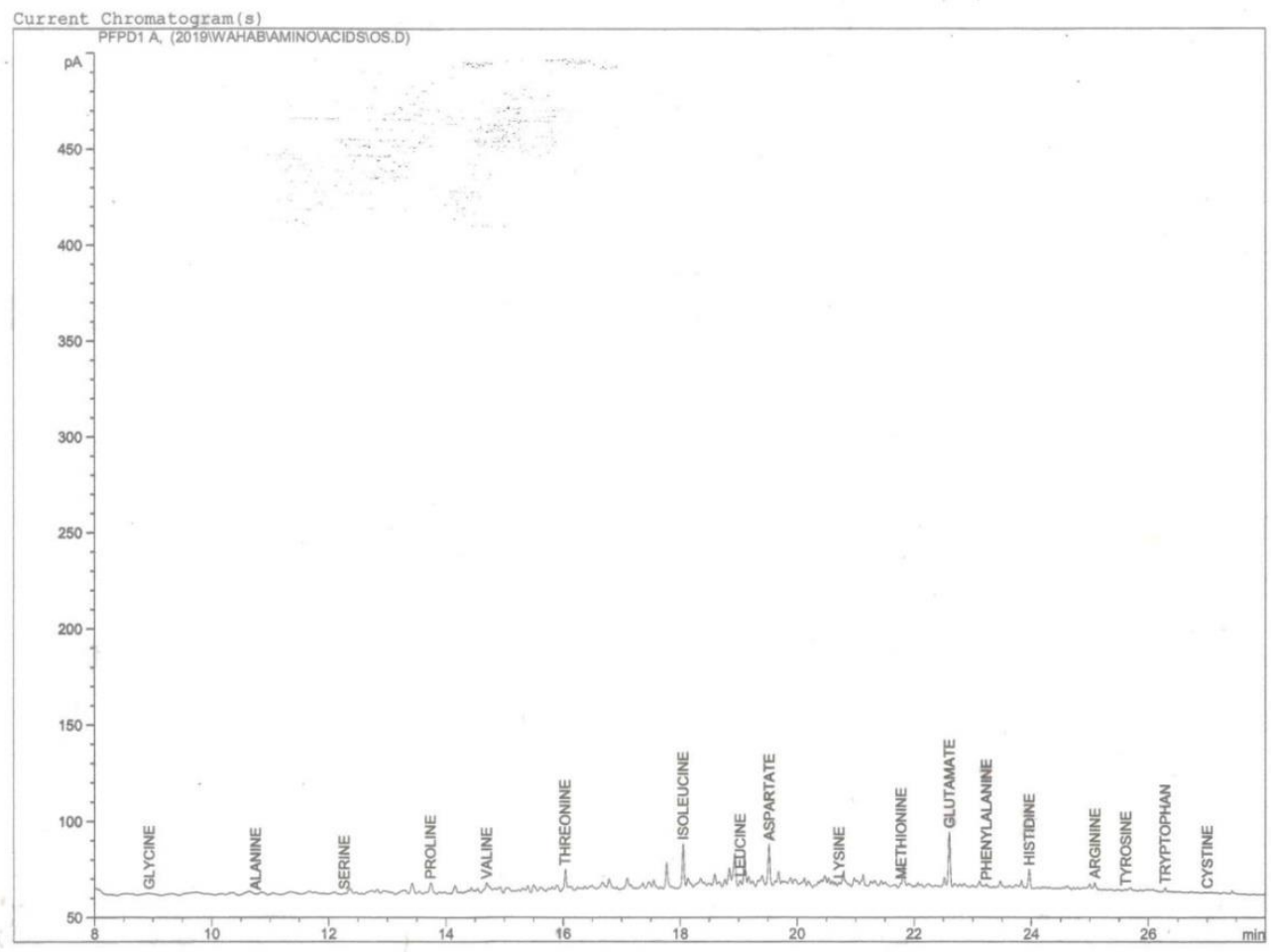

Figure 1: The chromatogram of Oven-dried sample for the Amino acid profile Print of window 38: Current Chromatogram(s)



Instrument 1 5/16/2019 3:01:29 PM

Figure 2: The chromatogram of Air-dried sample for the Amino acid profile 




Instrument 1 5/16/2019 3:03:24 PM

Figure 3: The chromatogram of Sun-dried sample for the Amino acid profile

Print of window 38: Current Chromatogram(s)

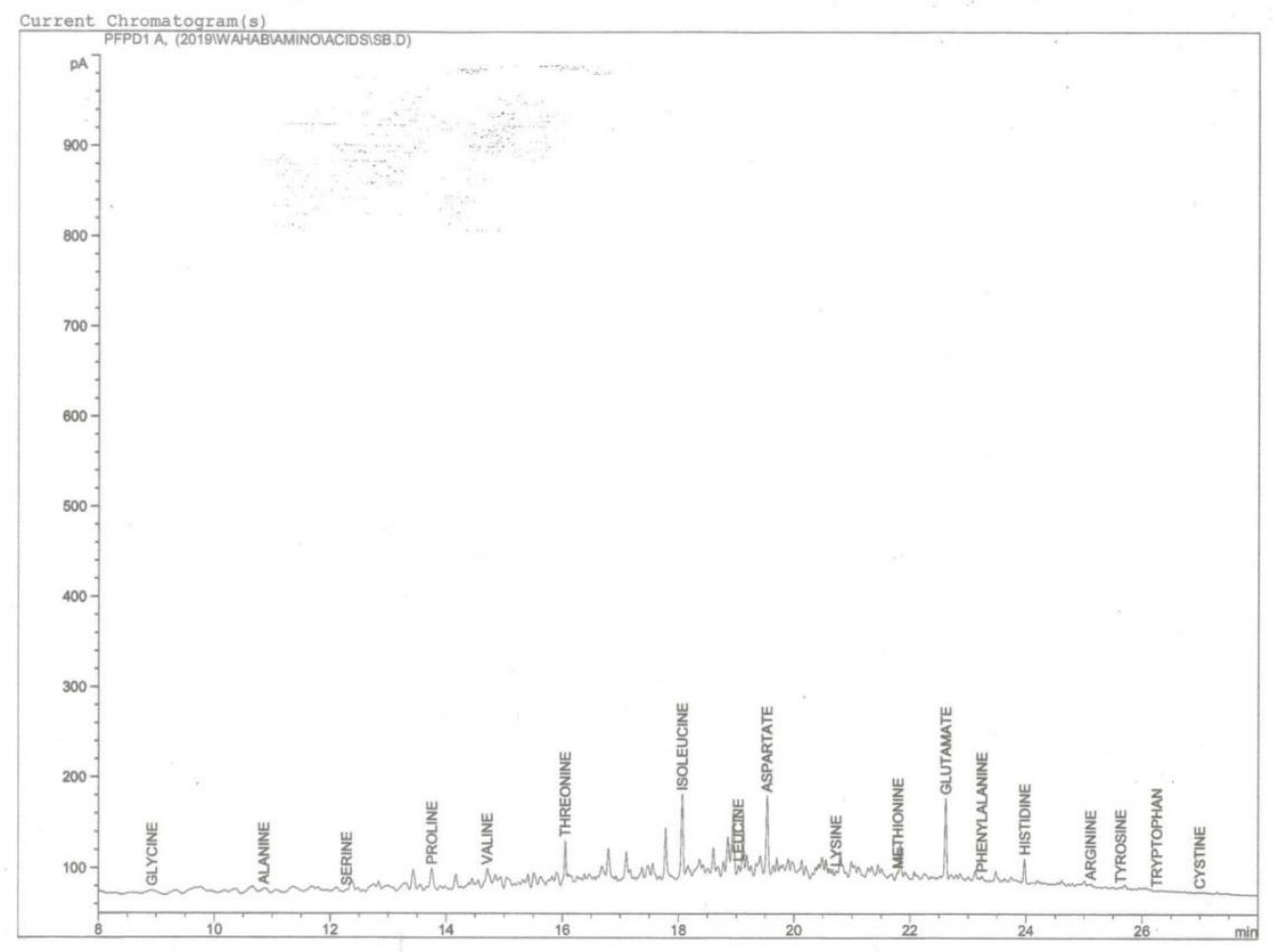

Figure 4: The chromatogram of Sun-dried back for the Amino acid profile 


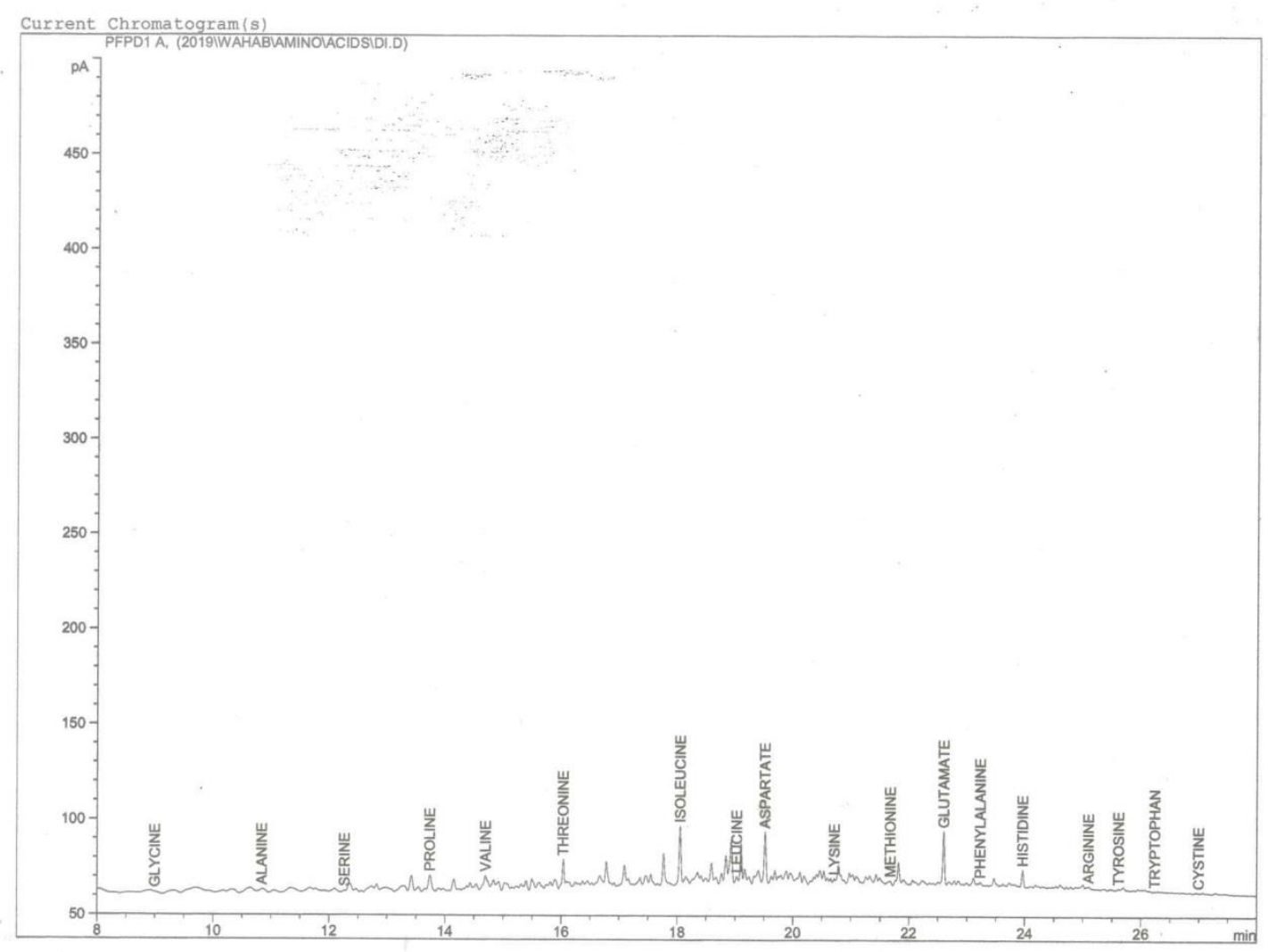

Figure 5: The chromatogram of Sun-dried inner (shell) for the Amino acid profile

The results in table 2 revealed all the essential amino acid content present in Thevetia peruviana seed sample which include; valine, threonine, isoleucine, leucine, methionine, phenylalanine, histidine and tryptophan for oven-dried, air-dried, sun-dried, sun-dried back and sun-dried shell respectively. The result also showed the total amino acid content for oven-dried, air-dried, sun-dried, sun-dried back and sun-dried shell: 27.012, 31.462, 27.894, 34.997 and 34.799 respectively.

Table 2: Essential Amino Acid Analysis of Thevetia peruviana seed (Amount g/100gProt)

\begin{tabular}{|l|c|c|c|c|c|c|}
\hline \multicolumn{1}{|c|}{ Parameters } & OD.S & AD.S & SD.S & SD.B & SD.I & $\begin{array}{c}\text { FAO/WHO } \\
\text { 1991 Standard }\end{array}$ \\
\hline Valine & 2.70395 & 4.65332 & 2.59809 & 5.28324 & 3.11040 & $\mathbf{3 . 5 0}$ \\
\hline Threonine & 3.45091 & 3.44314 & 3.38379 & 4.20768 & 4.38129 & $\mathbf{3 . 4 0}$ \\
\hline Isoleucine & 4.35529 & 4.30998 & 4.26463 & 3.94523 & 3.80203 & $\mathbf{2 . 8}$ \\
\hline Leucine & 6.97631 & 6.72565 & 6.62638 & 6.91056 & 8.81174 & $\mathbf{6 . 6}$ \\
\hline Lysine & 1.21984 & 4.11378 & 2.20719 & 5.18128 & 7.17860 & $\mathbf{5 . 8}$ \\
\hline Methionine & $6.57523 \mathrm{e}-1$ & 1.09555 & 1.07729 & 1.06573 & $9.05126 \mathrm{e}-1$ & $\mathbf{2 . 5 0}$ \\
\hline Phenylalanine & 3.56510 & 3.56218 & 3.50375 & 4.77190 & 4.06363 & $\mathbf{6 . 3}$ \\
\hline Histidine & 2.05957 & 2.39992 & 2.36997 & 2.54184 & 1.70727 & $\mathbf{1 . 9}$ \\
\hline Tryptophan & 2.02450 & 1.15922 & 1.86347 & 1.08720 & $8.39414 \mathrm{e}-1$ & $\mathbf{1 . 1}$ \\
\hline TOTAL & 27.012993 & 31.46274 & 27.89456 & 34.99766 & 34.79950 & $\mathbf{3 3 . 9}$ \\
\hline
\end{tabular}

Key: OD.S = Oven-dried sample, AD.S=Air-dried sample, SD.S=Sun-dried sample SD.B=Sun-dried back, SD.I=Sun-dried inner

The results of essential amino acids profile of the samples (OD.S, AD.S, SD.S, SD.B and SD.I) evaluated in this study is presented in Table 2. The values obtained for Leucine and Threonine are considerably higher than those of Bandara et al. (2010) except for Lycine from 
(OD.S, AD.S, SD.S, SD.B); methionine (OD.S, AD.S, SD.S, SD.B and SD.I); for phenylalanine from (OD.S, AD.S, SD.S, SD.B and SD.I) in this present study. Other components of essential amino acid profile obtained in this study such as Threonine, Isoleucine, Leucine, Tryptophan for all the sample (OD.S, AD.S, SD.S, SD.B and SD.I) are considerably higher than the standard values established by Zead et al. (2016). It was also discovered that the summation of essential amino acids obtained for samples evaluated in this study are lower than what is reported by (Ayoade et al., 2017) in the assessment of amino acid profile of (Anarium schweinfurthii) seed pulp but much more higher than what is reported by Farid et al. (2018) in the assessment of four (Rancho, Cartamar, Cartafri and Sharda) safflower (Carthamus tinctorius L) varieties grown in north-eastern Morocco. It was also discovered that the summation of essential amino acids obtained for samples evaluated in this present study are much higher than what is reported by Zead et al. (2016) for amino acid composition of the seeds, pulp and Rind from Citullus colocynthis fruits. Generally, sulphur rich amino acids (methionine and cystine) are limiting in most legumes.

Table 3 below presents the non-essential amino acids profile of the samples (SD.I, OD.S, SD.S, AD.S and SD.B) of Thevetia peruviana evaluated in this study. It also showed the total non- essential amino acid content of Thevetia peruviana seed sample for oven-dried, air-dried, sun-dried, sun-dried back and sun-dried shell which include: 59.042, 57.705, 62.894, 55.791 and 58.971 respectively.

Table 3: Non-essential Amino Acid Analysis of Thevetia peruviana seed (Amount g/100gProt.)

\begin{tabular}{|l|c|c|c|c|c|}
\hline \multicolumn{1}{|c|}{ Parameters } & OD.S & AD.S & SD.S & SD.B & SD.I \\
\hline Glycine & 2.98101 & 3.39747 & 3.11315 & 4.15813 & 4.68239 \\
\hline Alanine & 4.64324 & 4.43307 & 4.76172 & 3.78638 & 3.45696 \\
\hline Serine & 2.48013 & 2.73548 & 2.77310 & 4.60393 & 5.32994 \\
\hline Proline & 3.13797 & 3.08603 & 3.81932 & 3.78923 & 2.71241 \\
\hline Aspartate & 13.61202 & 13.48214 & 14.87346 & 11.58878 & 13.14201 \\
\hline Glutamate & 18.75948 & 16.64869 & 17.14940 & 16.42064 & 19.15407 \\
\hline Arginine & 9.54295 & 10.04062 & 13.08271 & 6.57786 & 5.57790 \\
\hline Tyrosine & 2.37463 & 2.02999 & 2.52827 & 3.51563 & 3.56760 \\
\hline Cystine & 1.51082 & 1.85196 & 1.79328 & 1.29055 & 1.34864 \\
\hline TOTAL & 59.04225 & 57.70545 & 62.89441 & 55.79113 & 58.97174 \\
\hline
\end{tabular}

Key: OD.S = Oven-dried sample, AD.S=Airdried sample, SD.S=Sun-dried sample SD.I=Sun-dried inner

From the result (table 3), Glutamate acid was discovered to have the highest mean value in the amino acid profile for all samples $(19.15,18.76,17.15,16.65$ and 16.42) respectively. This is an indication that all samples evaluated in this present study will most probably be recommended as flavouring or seasoning agents in the food industry. It was also discovered that the glutamic acid value in most and legumes Vigna species are considerably high. Soris 
and Mohan (2011) reported the following values for glutamic acid for Vigna aconitifolia, Vigna unguiculata (black), Vigna unguiculata (maroon); 16.12, 17.24 and 18.23 all in g/100g respectively.

Table 4 presents the summary of the amino acid profile of Thevetia peruviana for the seed, back and shell of oven dried sample(OD.S), air dried sample (AD.S), sun dried sample(SD.S), sun dried back(SD.B) and sun dried inner(SD.I). It shows the total essential amino acids, percentage essential amino acids, total non-essential amino acids, percentage non-essential amino acids and total sulphur amino acids which include (methionine and cysteine).

Table 4: Summary of amino acid profile of Thevetia peruviana seed (Amount $\mathrm{g} / \mathbf{1 0 0 g P r o t}$ )

\begin{tabular}{|l|c|c|c|c|c|}
\hline \multicolumn{1}{|c|}{ Parameters } & OD.S & AD.S & SD.S & SD.B & SD.I \\
\hline Total essential amino acids & 27.012993 & 31.46274 & 27.89456 & 34.99766 & 34.79950 \\
\hline \% Essential amino acids & 31.39030 & 35.28471 & 30.72461 & 38.57393 & 37.110995 \\
\hline Total non-essential amino acids & 59.04225 & 57.70545 & 62.89441 & 55.79113 & 58.97174 \\
\hline \% Non-essential amino acids & 68.60973 & 64.71527 & 69.27539 & 61.49221 & 62.88883 \\
\hline $\begin{array}{l}\text { Total Sulphur amino acids (methionine } \\
\text { + cysteine) }\end{array}$ & 2.16834 & 2.94751 & 2.87057 & 2.35628 & 2.25377 \\
\hline
\end{tabular}

Key: OD.S = Oven-dried sample, AD.S=Air-dried sample, SD.S=Sun-dried sample SD.I=Sun-dried inner

Table 4 present summary of the amino acid profile of Thevetia peruviana for oven-dried, airdried, sun-dried, sun-dried back and sun-dried shell. It shows the total essential amino acids, percentage essential amino acids, total non-essential amino acids, percentage nonessential amino acids and total sulphur amino acids which include (methionine and cysteine). The result is in agreement with Ayoade et al. (2017) for Canarium schweinfurthii seed and Zead et al. (2016) for Citrullus colocynthis fruits. The result is also in conformity with Akintelu and Amoo, (2016) for raw and boiled seed of Thevetia peruviana especially for glutamate acid.

Fatty acids characterisation of sun, oven and air dried Thevetia peruviana seed.

The percentage fatty acids composition of the oven-dried, sun-dried and air-dried sample of Thevetia peruviana seed is presented in Table 5. From the results, the main saturated fatty acids in oven-dried sample were found to be $25.73 \%$ which includes lauric acid (C12.0), tridecanoic acid (C13.0), pentadecanoic acid (C15.0), stearic acid (C18.0), arachidic acid (C20.0), behenic acid (C22.0) and lignoceric acid (C24.0). For Sun-dried it was found to be $3.29 \%$ and they are lauric acid (C12.0), tridecanoic acid (C13.0), pentadecanoic acid (C15.0) and stearic acid (C18.0). For air dried sample, the main saturated fatty acids had $40.54 \%$ which includes lauric acid (C12.0), tridecanoic acid (C13.0), myristic acid (C14.0), pentadecanoic acid (C15.0), palmitic acid (C16.0), stearic acid (C18.0), arachidic acid (C20.0), behenic acid (C22.0) and lignoceric acid (C24.0). Among the three techniques used tridecanoic acid (C13.0), had the highest percentage composition (air-dried), while myristic acid (C14.0), air-dried had the lowest percentage composition.

The main unsaturated fatty acids in oven-dried sample were $60.89 \%$ and they are oleic acid (C18:1) and linoleic acid (C18:2). The sun-dried sample were found to be $2.21 \%$ and they are oleic acid (C18:1) and linoleic acid (C18:2). The air-dried sample were found to be $20.4 \%$ and 
they are oleic acid (C18:1) and linoleic acid (C18:2). Oleic acid (56.32\%) was seen to produce the most abundant unsaturated fatty acid for the oven-dried sample while linoleic acid had $14.87 \%$ for the air-dried sample. Stearic acid was seen to produce the most $(19.11 \%)$ abundant saturated fatty acid for the oven-dried sample, while lauric acid had $1.12 \%$ for the sun-dried sample and tridecanoic acid $(21.66 \%)$ for air dried sample. Oleic acid had the highest percentage composition (oven-dried) while oleic acid had the least percentage composition (sun-dried).

Table 5: Fatty acid characterisation of sun, oven and air dried Thevetia peruviana seed

\begin{tabular}{|c|c|c|c|c|c|c|c|}
\hline \multirow[t]{2}{*}{ Parameters } & \multirow{2}{*}{$\begin{array}{c}\text { Peak area } \\
0.0313 \% \\
\text { Standard }\end{array}$} & \multicolumn{2}{|c|}{ Oven-dried sample } & \multicolumn{2}{|c|}{$\begin{array}{c}\text { Sun-dried } \\
\text { sample }\end{array}$} & \multicolumn{2}{|c|}{ Air-dried sample } \\
\hline & & $\mathrm{P} / \mathrm{A}$ & $\%$ & $\mathrm{P} / \mathrm{A}$ & $\%$ & $\mathrm{P} / \mathrm{A}$ & $\%$ \\
\hline${ }^{*}$ Lauric acid (C12:0) & 4.63 & 8.24 & 0.56 & 16.55 & 1.12 & 23.44 & 1.58 \\
\hline *Tridecanoic acid (C13:0) & 12.60 & 82.25 & 2.04 & 21.24 & 0.54 & 871.86 & 21.66 \\
\hline${ }^{*}$ Myristic acid (C14:0) & 186.27 & - & - & - & - & 10.63 & 0.018 \\
\hline *Pentadecanoic acid (C15:0) & 3.82 & 45.61 & 3.74 & 9.41 & 0.77 & 30.66 & 2.51 \\
\hline *Palmitic acid (C16:0) & - & - & - & - & - & 27.95 & 0.07 \\
\hline *Stearic acid (C18:0) & 66.69 & 4072.13 & 19.11 & 184.06 & 0.86 & 2047.16 & 9.61 \\
\hline **Oleic acid (C18:1) & 66.93 & 12043.2 & 56.32 & 182.35 & 0.85 & 1197.17 & 5.60 \\
\hline **Linoleic acid (C18:2) & 81.16 & 1184.30 & 4.57 & 353.03 & 1.36 & 3854.71 & 14.87 \\
\hline${ }^{*}$ Arachidic acid (C20:0) & 198.84 & 129.50 & 0.42 & - & - & 49.44 & 0.08 \\
\hline *Behenic acid (C22:0) & 209.34 & 137.94 & 0.21 & - & - & 18.96 & 0.03 \\
\hline *Tricosanoic acid (C23:0) & 219.63 & - & - & - & - & - & - \\
\hline *Lignoceric acid (C24:0) & 229.82 & 48.14 & 0.07 & - & - & 35.18 & 0.05 \\
\hline Group total & & & 87.04 & & 5.5 & & 56.08 \\
\hline Total Amount Saturated & & & 26.15 & & 3.29 & & 35.61 \\
\hline Total Amount Unsaturated & & & 60.89 & & 2.21 & & 20.47 \\
\hline NOTE: $*=$ Saturated, ${ }^{* *}=$ Uns $a$ & & & & & & & \\
\hline
\end{tabular}

From the result obtained in table 5, the total saturated fatty acid is $(3.29-35.61)$ C12.0 to C24.0. The highest among them is recorded in air-dried (21.66) while Myristic acid (0.018) had the lowest percentage composition. The result present in this study was lower than (47.20 -51.00\%) reported by Nfor et al.(2014) for GUD, WF and RB cow breeds, but lower than $(65.38-65.67 \%)$ reported by Pilarczyk et al.(2015) for HF and S cow breeds. It was also 
discovered that an increase in the amount of the fatty acids in the oven-dried sample was observed except lauric acid where there is a slight reduction from $1.58 \%$ to $0.56 \%$; the increase can be related to the high temperature of the oven when drying which has been reported by Ngassapa et al. (2012) for palm oil, sesame oil and sunflower oil. Also, Akintelu and Amoo (2016) reported for the fatty acid composition of raw and boiled sample of Thevetia peruviana where similar fatty acids [myristic acid (C14:0), palmitic acid (C16:0), stearic acid (C18:0), oleic acid (C18:1), linoleic acid (C18:2), arachidic acid (C20:0) and behenic acid (C22:0)] were obtained. The significant increase in the amount of fatty acid can be seen in oleic acid followed by stearic acid making them the most abundant fatty acids in the oven-dried sample.

\section{Conclusion}

This research work has given insight into amino acid profile and fatty acid characterization of the seed of Thevetia peruviana. It was concluded that the essential amino acids profile of the samples is considerably higher than the standard value of FAO/WHO. It is therefore within the minimum standard. For the non-essential amino acids profile, Glutamate acid was discovered to have the highest mean value in the profile for all samples. The high levels of glutamate and aspartate acids could be due to the experimental conditions that could cause the transformation of glutamine and asparagine into glutamate and aspartate acids respectively. This is an indication that all samples evaluated in this present study will most probably be recommended as flavouring or seasoning agents in the food industry. Also, the high contents of unsaturation of the fatty acid of the seed oil indicated the oil as a good source of unsaturation which increases the shelf life and edibility of the oil.

\section{Recommendation}

Further studies on production of glutamate salt from the seed is hereby recommended.

\section{References}

Akintelu, M. T. and Amoo, I. A. (2016). Proximate Characterisation and Physicochemical Properties of Raw and Boiled Milk Bush Seed (Thevetia Peruviana). International Journal of Sciences, 5(3): 17-21.

Akintelu, M. T. and Amoo, I. A. (2017). Evaluation of Fatty Acid, Amino Acid and Phytochemical Composites of Raw and Boiled Milk Bush Seed (Thevetia Peruviana). SAU Science-Tech Journal, 2(1): 31-39.

Official Methods of Analysis of the Association of Analytical Chemists (2005). 18 th Edition, Washington, D. C. U.S.A.

Ayoade, G. W., Amoo, I. A., Jabar, J. M and Maduawudia, C. O (2017). Proximate, Minerals and Amino Acid Profile of (Canarium schweinfurthii) Seed Pulp. International Journal of Science and Technology, 1(2): 657-661.

Bandara, V., Weinstein, S. A., White, J. and Eddleston, M. (2010). A Review of the Natural History, Toxicology, Diagnosis \& Clinical Management of Nerium Oleander (Common Oleander) \& Thevetia Peruviana (Yellow Oleander) Poisoning. Toxicon, 56(3): 273-281.

Clark, V.P and Creswell, J. (2007). Designing and Conducting mixed methods Research, Thousand Oaks, CA:Sage

Damila, R.M; Eliza, M. R; Sheisa, C. S; Elton, G.B; Rubia, M.S; Nilson, E. S; Makoto, M. and Jesui, V. V. (2017). Proximate Composition, Mineral Contents and Fatty Acid Composition of the Different Parts and Dried Peels of Tropical Fruits Cultivated in Brazil. J. Braz. Chem. Soc., (28): 308-318. 
Danka, P.O, Dobrina, D.T. and Kalin, V.I. (2012). Simultaneous Identification and Determination of Total Content of Amino Acids in Food Supplements- Tablets by Gas Chromatography Asian Journal of Pharmaceutical and Clinical Research, 5(S): 12.

FAO/WHO. (1991). Protein quality evaluation. Food and Agricultural Organization of the United Nations. Rome: FAO, 1-66.

Farid, M.; Abdessamad, B.M.; Gaetan, R.; Marie-Laure, F.; Marianne, S.; Ahmed, E. and Hana, S.C. (2018). Proximate Composition, Amino acid profile, Carbohydrate and Mineral content of Seed meals from four safflower (Carthamus tinctorius L.) varieties grown in north-eastern Morocco. OCL 25(2): A202

Iorliam, B.E and Yarkwan, B. (2013) "Histidine Biosynthesis". The Arabidopsis Book. 9:e0141.

Koushik, M., Arkendu, C., Somenath, B., Raj, B., Sonia, A. and Injamul, H. (2016). A Review on Various Biological and Pharmacological Properties of Thevetia Peruviana. International Journal of Advanced Research in Biological Sciences, 3(9): 178-182.

Nfor B.M., Corazzin, M., Fonteh, F.A., Sepulcri, A., Aziwo, N.T.,Piasentier,E. (2014). Fatty acid profile of zebu beef cattle from the Central African sub-region. South African Journal of AnimalScience.44 (2):148-154.

Ngassapa, F. N., Nyandoro, S. S. and Mwaisaka, T. R. (2012). Effects of Temperature on the Physicochemical Properties of Traditionally Processed Vegetable Oils and their Blends. Tanz. Journal of Science, 38(3): 166-176.

Ogara, R. S. (2013). Evaluation of Nutritional Properties of Yellow Oleander (Thevetia Peruviana) Seeds in Kenya. Food Science and Quality Management, (22) 88-94.

Oluwaniyi, O. O, Ibiyemi, S. A, Olatunji G. A and Apata. D. F (2011). Amino Acid Analysis and Biological Evaluation of Detoxified Thevetia Seed Meal. African Journal of Food, Agricultural, Nutrition and Development, 11(7): 5510 - 5524

Pilarczyk, R., Wójcik, J., Sablik, P. and Czerniak, P. (2015). Fatty acid profile and health lipid indices in the raw milk of Simmental and Holstein-Friesian cows from an organic farm. South African Journal of Animal Science.2015, 45, 30-38.

Rajapaske, S. (2009). Management of Yellow Oleander Poisoning. Clinical Toxicology, 47(3), 206-212.

Roberts, D. M., Southcott, E., Potter, J. M. and Buckley, N. A. (2006). Pharmacokinetics of Digoxin Cross-Reacting Substances in Patients with Acute Yellow Oleander (Thevetia Peruviana) Poisoning, Including The Effect of Activated Charcoal. Therapeutic Drug Monitoring, 28(6): 784-792

Simoni, R.D., Hill, R.L. and Vaughan, M. (2002). The discovery of the amino acid threonine: the work of William C. Rose. The Journal of Biological Chemistry. 277(37): 25

Singh, K., Agrawal, K. K., Mishra, V., Uddin, S. M. and Shukla, A. (2012). A Review on: Thevetia Peruviana. International Research Journal of Pharmacy, 3(4): 74-77.

Soris, P. T and Mohan, V. R (2011) Chemical Analysis and Nutritional Assessment of Two Less Known Pulses of Genus Vigna. Tropical and Subtropical Agroecosystems, 14(2): 473-484

Stryer, L.; Berg, J. and Tymoczko, J. (2002). Biochemistry. W.H. Freeman \& Co Ltd. 1438 p. ISBN 978-0716746843.

Usman, H., Abdulrahman, F.I and Afri, J.T. (2009) Traditional, Complementary and Alternative Medicine. 6(3): 289-295.

Zead, H.M.A.; Haiane, R.L.; Petro, S.; Ivan C.; Ihab, I.A.; Khaldun, M.A. and Loay, K.M.H (2016).Comparative Study of Amino Acid Composition in the Seeds, Pulp and Rind from Citurllus colocynthis Fruits. International Journal of Pharmacognosy and Phytochemical Research, 8(3): 433-437. 